\title{
EFFECTS OF EXOGENOUS ARACHIDONIC ACID ON MORPHOLOGICAL TRAITS AND FATTY ACID PROFILE OF RICE (Oryza sativa L.) GROWN ON SALINE SOIL
}

\author{
PUTERI AFIQAH ABDUL WAHAB AND AZIZ AHMAD*
}

\author{
School of Fundamental Science, Universiti Malaysia Terengganu, \\ 21030 Kuala Nerus, Terengganu, Malaysia
}

\section{*Corresponding author:aaziz@umt.edu.my}

\begin{abstract}
Salinity is one of the major constraints in the rice production worldwide. Rice plants have moderate tolerance towards salinity. Salinity changes cell membrane permeability and fatty acid compositions by releasing the free fatty acids. Nonetheless, the effect of exogenous fatty acid such as arachidonic acid (AA) on rice grown on saline soil is yet unknown. The objective of the current study is to determine the effect of AA on the morphological traits and free fatty acids of rice plant grown under saline conditions. Rice plants grown on saline soil $(E C=12 \mathrm{ds} / \mathrm{m})$ were treated with $50 \mu \mathrm{M}$ AA on day 45 after transplant. Leaves and panicles were sampled after two weeks of treatment and analysed for fatty acid profile using GC-MS. The morphological traits were observed at the maturity stage. Results showed that AA treatment improved the grain fill-in of the saline stress rice and reduced the accumulation of free fatty acids in the cell. The AA treatment also increased the linoleic acid (18:2), linolenic acid (18:3) in panicles and, dihomo- $\gamma$-linolenic acid (20:3) and nervonic acid (24:1) in leaves. The finding suggests that exogenous AA regulates salinity stress in rice by reducing the accumulation of free fatty acids.
\end{abstract}

Keywords: arachidonic acid, panicle, spikelet, polyunsaturated fatty acid, Oryza sativa

\section{Introduction}

Climate change has a big impact on soil performance and functions (Dasgupta et al., 2015), which affects the agriculture sectors. Salinization (Hou et al., 2016) and accumulation of salt in soil (Reddy \& Crohn, 2014) are among abiotic factors that contribute to crop production and yield. Saline soil is soil that has an electrolyte concentration (EC) of 4 decisiemens per meter $(\mathrm{dS} / \mathrm{m})$ or higher (Amacher et al., 2000). Salinity inhibits plant growth and productivity through osmotic stress and ion toxicity (Tarakcioglu \& Inal, 2002). Higher soluble salt in the soil will change the soil $\mathrm{pH}$, nutrient imbalance, reduce water infiltration, and cause accumulation of toxic element in the plant (Tarakcioglu \& Inal, 2002; Sacała et al., 2011).
Rice (Oryza sativa L.) is one of the most important cereal crops and a leading staple food in the world (Reddy et al., 2017). Generally, rice is sensitive to $\mathrm{pH}$ changes (Huang et al., 2017) but moderately tolerant to salinity (Aguilar et al., 2017). Under high salinity condition, rice plant exhibits leaf chlorosis, stunted growth, failure of spikelet development and seedling establishment and reduction in gain yield (Khan et al., 1997; Ali et al., 2004). When the EC of the soil exceeds $6 \mathrm{dS} / \mathrm{m}$, the grain yield decrease is about $60 \%$ to $100 \%$ (Kibria et al., 2017). Nonetheless, rice sensitivity towards salinity varies during growth phases (Tadesse et al., 2017). At the vegetative and early reproductive phase, saline effects the panicle initiation and tillering (Zeng et al., 2001; Balkan et al., 2015; Aguilar et al., 2017). Rice is relatively salt tolerant during ripening phase (Khan et al., 1997; Zeng et al., 
2001) and differs among cultivars (Tadesse et al., 2017).

Plant cell contains the plasma membrane comprising bilayer phospholipids that protects the intercellular component of a cell and control the movement of materials across the cell (Roualdes \& Rouessac, 2017). Thus, plasma membrane in root cell is an important organ that is directly exposed to saline conditions (Mansour, 2013). In the presence of excessive salt, the plasma membrane will alter its permeability, membrane lipid compositions and the activity of membrane bound enzyme (Salama et al., 2007). As plant experience stresses such as wounding or increasing amount of soluble salt, the plasma membrane releases the FFA (Conconi et al., 1996; Scholz et al., 2015) Endogenous FFAs released into the cell is converted to jasmonates, a lipid-derived hormone that includes jasmonic acid, methyl ester jasmonic acid and amino acid conjugates that involve specific gene activation and a series of enzymatic reactions (Lyons et al., 2013; Yuan \& Zhang, 2015). The $\alpha$-linolenic acid is the precursor for jasmonates biosynthesis catalysed by lipoxygenase enzyme to form the 13(S)-hydroperoxy linolenic acid and converted into several intermediates via oxidation process (Schaller et al., 2004; Lyons et al., 2013; Yuan \& Zhang, 2015). In plants including rice, jasmonates play a major role in plant development such as seed germination, root growth, reproduction and senescence and plant defence (Browse, 2009; Fonseca et al., 2009). Jasmonates control the transition of spikelet meristem to flower meristem (Cai et al., 2014) of rice. Spikelet is important for the formation of floral organ determination and grain yield of rice (Tanaka et al., 2014).

AA is a polyunsaturated fatty acid and abundantly present in plasma membrane as a phospholipids. Previous study by Tian et al. (2014) reported that AA was released from the membrane cell as a response to stresses or during pathogen attacks (Garcia-Pineda \& Lozoya-Gloria, 1999). The phospholipase A2 enzyme catalysed the linoleic acid and $\alpha$ linolenic acid in the cell membrane into free
AA (Adam et al., 2008). The accumulation of AA triggers the biosynthesis and accumulation of phtyoalexin, chitinase, lignin and ethylene production (Küpper et al., 2009). To date, the effect of exogenous AA on rice growth under saline conditions remains unknown. Therefore, the objective of this study is to determine the effect of exogenous AA on the morphological traits and endogenous FA composition of Oryza sativa L. grown under saline conditions. It was hypothesized that the exogenous AA improve the morphological traits and alter the accumulation of free fatty acid profile in rice plants.

\section{Materials and Methods Study Site}

Rice plants were planted and grown under shade in the greenhouse at Universiti Malaysia Terengganu (UMT), Kuala Nerus, Terengganu from September 2017 to January 2018. Biochemical analysis was carried out at Institute of Marine Biotechnology, UMT.

\section{Seedling Preparation and Arachidonic Acid Treatment}

Treatment was carried out using the saline soil taken from Kemasin, Bachok Kelantan and filled up in a trough. The soil EC was measured using EC meter and adjusted to a range of 10 to $12 \mathrm{dS} / \mathrm{m}$ with sea water obtained from sea near to UMT beach. For seedling preparation, the soil mixture consisting of top soil, river sand and organic matter at ratio of 3:2:1 was prepared. The salinity-tolerant genotypes namely SS1-41 [CSR28] was obtained from the International Rice Research Institute (IRRI), Los Banos and Laguna, Philippines. One hundred seeds were soaked in tap water overnight. After soaking, the seeds were kept moist and in warm temperature $\left(35^{\circ} \mathrm{C}\right)$ to allow germination prior to being transferred to the soil. The water level was maintained in a range of 1-3 cm height. NPK green fertilizer was applied on day 14 at 9 grams/trough. On day 20, the healthy plantlets were transplanted into saline soil in a trough. A randomized block design was used with three replicates (three 
troughs; 15 plants per trough), where the plants were sown in three rows with five plants for each row. The water level was maintained in a range of 4-5 cm height. Fertilizer was applied on day 40, 18 grams of NPK green and 3 grams of urea per trough. AA was prepared in $0.05 \%$ (v/v) of Tween 20 at concentration of $50 \mu \mathrm{M}$ prior to application on rice foliar. On day 45, 12 $\mathrm{mL}$ of $50 \mu \mathrm{M}$ AA solutions was sprayed on foliar of six treatment plants, while the control plants were sprayed with $12 \mathrm{~mL}$ of $0.05 \%(\mathrm{v} / \mathrm{v})$ Tween 20. On day 60, 19 grams of fertilizer (NPK blue) was given to each trough; fertilizer regime was based on recommendation by MARDI.

\section{Sampling and Morphological Traits Analysis}

On day 55, leaves and panicles were taken from each trough for both control and treatment plants. Six leaves and panicles were sampled; a total of 36 samples were collected and used for oil extraction and fatty acids analysis. The leftover plants were used for morphological measurement (Table 1). The morphological traits were measured between day 70 (middle of reproductive stage) and day 120 (ripening stage).
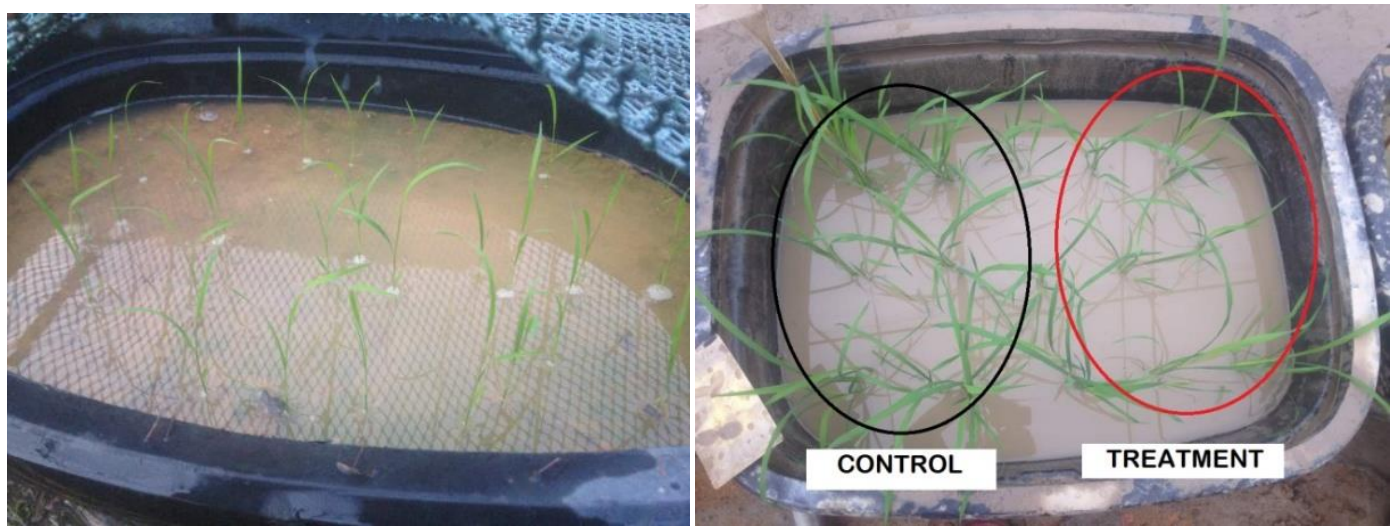

Figure 1: Rice plants on Day 7 (A), the position of treatment and control rice plants on saline soil in the trough (B)

\section{Oil Extraction}

Samples were oven-dried at $60{ }^{\circ} \mathrm{C}$ and measured for dry weight. Oil extraction was carried out based on methods by Cha et al. (2011). The dried samples were powdered and mixed with $\mathrm{HCl}_{\text {conc }}$ at ratio $0.1: 2(\mathrm{~g}: \mathrm{mL})$, then incubated in boiling water bath for $15 \mathrm{~min}$. Then, hexane $(2 \mathrm{~mL})$ was added into the mixture and vigorously vortexed. The extraction was repeated twice with $2 \mathrm{~mL}$ of hexane. The upper layer of the mixture was transferred into an empty rotary-evaporator flask, incubated in a water bath at $60{ }^{\circ} \mathrm{C}$ that had been previously fixed with rotary evaporatory system. The pressure of suction was set to 335 mbar. The oil obtained in the flask was transferred into a vial and dried overnight in oven at $70{ }^{\circ} \mathrm{C}$ until a constant weight was obtained.

\section{Fatty Acid Methyl Esterification}

Fatty acid esterification to methyl esters followed the methods used by Cha et al. (2011). Oil $(50 \mathrm{mg}$ ) was transferred to condenser flask, and four pieces of boiling chips and $4 \mathrm{~mL}$ of 0.5 $\%$ methanolic $\mathrm{NaOH}$ were added. Then, Lieberg condensers were attached to the flask and the mixture was heated on a heating mantle for $3 \mathrm{~min}$. While the heating process took place, $5 \mathrm{~mL}$ of $20 \%$ boron-trifluoride methanol (BF3$\mathrm{MeOH}$ ) and $2 \mathrm{~mL}$ of $\mathrm{n}$-heptane were added into the mixture respectively. The flask was removed from heating mantle and the Lieberg Condensor after the vapours had been condensed. Fifteen $\mathrm{ml}$ of saturated sodium chloride was added and mixed well. The mixture was transferred into a $50 \mathrm{~mL}$ test tube and the upper layer of the mixture was shifted 
into $5 \mathrm{~mL}$ bijou bottle containing sodium sulphate anhydrous. The FAME obtained was filtered using syringe filter (nylon $0.4 \mu \mathrm{m}$ ) and ready for gas chromatography analysis.

\section{Mass Spectrometry-Gas Chromatography $(G C-M S)$}

FAME was analyzed using gas chromatography equipped with $0.25-\mathrm{mm}$ of ionization detector, Rtx5MS-30m capillary column and single 150 psi EPC split-splitless injection ports. Helium was used as carrier gas at a constant flow rate of $1 \mathrm{~mL} /$ minute. The temperature of injector was set to $300{ }^{\circ} \mathrm{C}$. The oven temperature was set to $100{ }^{\circ} \mathrm{C}$ for 10 minutes for isothermal heating and was increased to $300^{\circ} \mathrm{C}$ for 20 minutes at a rate of $10{ }^{\circ} \mathrm{C}$ per minute. Final oven temperature was held for 10 minutes. The individual fatty acid compositions were identified by comparison between retention times of FAME library from the MS-GC.

\section{Statistical Analysis}

Data were statistically normalized and analyzed using the multi-variance analysis. The significant different of mean was identified with a $t$-test, $p=0.05$.

\section{Results and Discussion Morphology Traits}

Table 1 shows the morphological traits of rice plants treated with exogenous AA and control. The leaf length of control plants were significantly $(p<0.05) 1.14$-fold higher than treatment plants. A similar trend was observed on the plant height, which were 1.12-fold higher than treatment plants. On the other hand, the tiller number per plant, panicle length and spikelet number per panicle did not significantly differ between treatment and control (Table 1). The spikelet number was in range of 68 to 96 per panicle. Interestingly, the number of filled grain per panicle was significantly higher $(p<0.05)$ in treatment, which was 3.23-fold higher compared to the control.

Table 1: The morphology traits of rice treated with arachidonic acid and control. Values with same small capital letter in the same role did not significantly different. Data are mean $\pm \mathrm{sd}$ $(\mathrm{n}=3), \mathrm{p} \leq 0.05$ significant different using $t$ test.

\begin{tabular}{lccl}
\hline Morphological traits & Control & $\begin{array}{c}\text { AA } \\
\text { Treatment }\end{array}$ & $\begin{array}{c}\boldsymbol{p} \text { value } \\
(\boldsymbol{t} \text {-test })\end{array}$ \\
\hline Leaf length $(\mathrm{cm})$ & $75.8 \pm 1.2^{\mathrm{a}}$ & $66.1 \pm 4.1^{\mathrm{b}}$ & 0.0452 \\
Plant height $(\mathrm{cm})$ & $80.7 \pm 1.4^{\mathrm{a}}$ & $71.6 \pm 3.4^{\mathrm{b}}$ & 0.0315 \\
Tillers number/plant & $8.6 \pm 0.5^{\mathrm{a}}$ & $7.6 \pm 0.5^{\mathrm{a}}$ & 0.1012 \\
Panicle length $(\mathrm{cm})$ & $17.9 \pm 0.6^{\mathrm{a}}$ & $19.3 \pm 1.5^{\mathrm{a}}$ & 0.2609 \\
Spikelet number/panicle & $79 \pm 11^{\mathrm{a}}$ & $82 \pm 14^{\mathrm{a}}$ & 0.7651 \\
Filled grain/Panicle & $12 \pm 3^{\mathrm{b}}$ & $42 \pm 12^{\mathrm{a}}$ & 0.0443 \\
Percentage of filled grain/panicle $(\%)$ & $15.4 \pm 2.5^{\mathrm{b}}$ & $45.7 \pm 1.9^{\mathrm{a}}$ & 0.0001 \\
\hline
\end{tabular}

Salinity is one of the crucial factors that limits the rice growth and productivity. In rice, saline stress gives crucial effects on vegetative phase and early reproductive stage. Leaf chlorosis, stunted growth, failure of spikelet development and seedling establishment and reduced grain yield were the symptoms showed by salt-affected rice (Khan et al., 1997; Ali et al., 2004). A recent study showed that when the
EC of the soil exceed $6 \mathrm{dS} / \mathrm{m}$, reduction in grain yield from its maximal yield performance decreased about $60 \%$ to $100 \%$ (Kibria et al., 2017). Our results showed that the measured morphological traits-leaf length, plant height and tiller number-were not improved by the AA treatment. However, the filled grain was improved by the AA treatment. Rice grain filling is associated with grain nitrogen 
concentration (Wei et al., 2018), which has higher salinity levels of $\mathrm{K}^{+}$and $\mathrm{NO}_{3}{ }^{-}$commonly in low concentrations (Gosh et al., 2016). This result suggests that exogenous AA managed to reduce the salinity stress and permit the grain filling activity.

\section{Fatty acid profile}

AA altered the FFA composition in both leaves and panicles of AA treated plants. The results showed that the fatty acid spectrum in both AA treated samples and control contained various types of saturated fatty acids from $4 \mathrm{C}$ to $24 \mathrm{C}$ and unsaturated fatty acids from $14 \mathrm{C}$ to $24 \mathrm{C}$ (Table 2). Major fatty acids were significantly increased in the AA treated samples, which were the $C 20: 3$ and $C 24: 1$ in leaves, $C 18: 2$ and C18:3 in panicles (Table 2).

Nervonic acid (C24:1) was the most abundant fatty acid the rice leaves. It was 2.57 $\mathrm{mg} / \mathrm{mg}$ and $6.38 \mathrm{mg} / \mathrm{mg}$ of sample in control and AA treatments, respectively. This result exhibited an increment of C24:1 up to 3.81 $\mathrm{mg} / \mathrm{g}$ of sample in the leaves of AA treatment. Meanwhile, the $\mathrm{C} 24: 1$ in panicles was 3.62 $\mathrm{mg} / \mathrm{mg}$ and $2.26 \mathrm{mg} / \mathrm{mg}$ of sample in both control and AA treatments, respectively. This showed a reduction of C24:1 $(1.36 \mathrm{mg} / \mathrm{g}$ of sample) in the panicles of AA treatment. Results also showed that salinity stress triggered higher accumulation of free FA C24:1 in leaves compared to panicles in the AA treated plants (Figure 2). This suggests that the long chains monounsaturated fatty acid C24:1 may be involved in stress regulation in the leaves during the early reproductive stage. To our knowledge, this is the first report on the presence of C24:1 in rice plants. The FA is a very long chain fatty acid that has been found only on the seed oils of few plants (Huai et al., 2015). 
Table 2: Fatty acid composition of leaves and panicles from AA treated and control plants.

\begin{tabular}{c|ccc|ccc}
\hline $\begin{array}{c}\text { Fatty } \\
\text { Acid }\end{array}$ & $\begin{array}{c}\text { Control } \\
\text { Leaf } \\
\text { (CL) }\end{array}$ & $\begin{array}{c}\text { Treatment } \\
\text { Leaf } \\
\text { (TL) }\end{array}$ & $\boldsymbol{\Delta}$ TL-CL & $\begin{array}{c}\text { Control } \\
\text { Panicle } \\
\text { (CP) }\end{array}$ & $\begin{array}{c}\text { Treatment } \\
\text { Panicle } \\
\text { (TP) }\end{array}$ & $\Delta$ TP-CL \\
\hline C4:0 & 0.75 & 0.12 & -0.63 & 0.03 & 0.04 & 0.01 \\
C6:0 & 0.02 & - & -0.02 & 0.03 & - & -0.03 \\
C8:0 & 0.14 & 0.06 & -0.08 & 0.06 & 0.05 & -0.01 \\
C10:0 & 0.00 & 0.02 & 0.02 & 0.05 & - & -0.05 \\
C12:0 & 0.06 & 0.05 & -0.01 & - & 0.06 & 0.06 \\
C14:0 & 0.12 & 0.07 & -0.05 & - & 0.06 & -0.06 \\
C14:1 & 0.02 & 0.09 & 0.07 & 0.07 & 0.15 & 0.08 \\
C15:0 & 0.23 & 0.09 & -0.14 & 0.15 & 0.10 & -0.05 \\
C15:1 & 0.87 & 0.40 & -0.47 & 0.41 & 0.36 & -0.05 \\
C16:0 & $\mathbf{3 . 3 0}$ & $\mathbf{1 . 3 7}$ & $\mathbf{- 1 . 9 3}$ & $\mathbf{2 . 3 0}$ & $\mathbf{0 . 0 6}$ & $\mathbf{- 2 . 2 4}$ \\
C17:0 & 0.44 & 0.19 & -0.25 & 0.13 & 0.02 & -0.11 \\
C17:1 & 0.11 & - & -0.11 & - & 0.15 & 0.15 \\
C18:0 & 0.27 & 0.29 & 0.02 & 0.75 & 0.18 & -0.57 \\
C18:1 & 0.28 & 0.21 & -0.07 & 0.12 & 0.16 & -0.04 \\
C18:2 & $\mathbf{1 . 2 1}$ & $\mathbf{0 . 1 1}$ & $\mathbf{- 1 . 1 0}$ & $\mathbf{0 . 4 4}$ & $\mathbf{1 . 0 3}$ & $\mathbf{0 . 5 9}$ \\
C18:3 & $\mathbf{0 . 3 3}$ & $\mathbf{0 . 1 6}$ & $\mathbf{- 0 . 1 7}$ & $\mathbf{0 . 2 8}$ & $\mathbf{2 . 5 8}$ & $\mathbf{2 . 3 0}$ \\
C20:0 & 0.19 & 0.09 & -0.10 & 0.13 & 0.08 & -0.05 \\
C20:1 & 0.01 & 0.16 & 0.15 & 0.30 & 0.10 & 0.70 \\
C20:3 & $\mathbf{0 . 7 9}$ & $\mathbf{2 . 0 2}$ & $\mathbf{1 . 2 3}$ & 0.53 & 0.61 & 0.08 \\
C20:4 & 0.02 & 0.06 & 0.04 & 0.03 & 0.07 & 0.04 \\
C20:5 & 0.06 & 0.12 & 0.06 & 0.07 & 0.04 & -0.03 \\
C22:0 & 0.00 & 0.22 & 0.22 & 0.14 & 0.18 & 0.04 \\
C22:1 & 1.12 & 0.07 & -1.05 & 0.08 & 0.20 & 0.12 \\
C22:2 & 0.02 & 0.04 & 0.02 & 0.02 & 0.11 & 0.09 \\
C22:6 & 0.03 & 0.12 & 0.19 & 0.21 & 0.10 & 0.11 \\
C23:0 & 0.13 & 0.36 & 0.23 & 0.03 & 0.19 & 0.16 \\
C24:0 & 1.91 & 0.17 & -1.74 & 0.30 & 0.21 & -0.09 \\
C24:1 & $\mathbf{2 . 5 7}$ & $\mathbf{6 . 3 8}$ & $\mathbf{3 . 8 1}$ & $\mathbf{3 . 6 2}$ & $\mathbf{2 . 2 6}$ & $\mathbf{- 1 . 3 6}$ \\
\hline & & & & & & \\
\hline
\end{tabular}



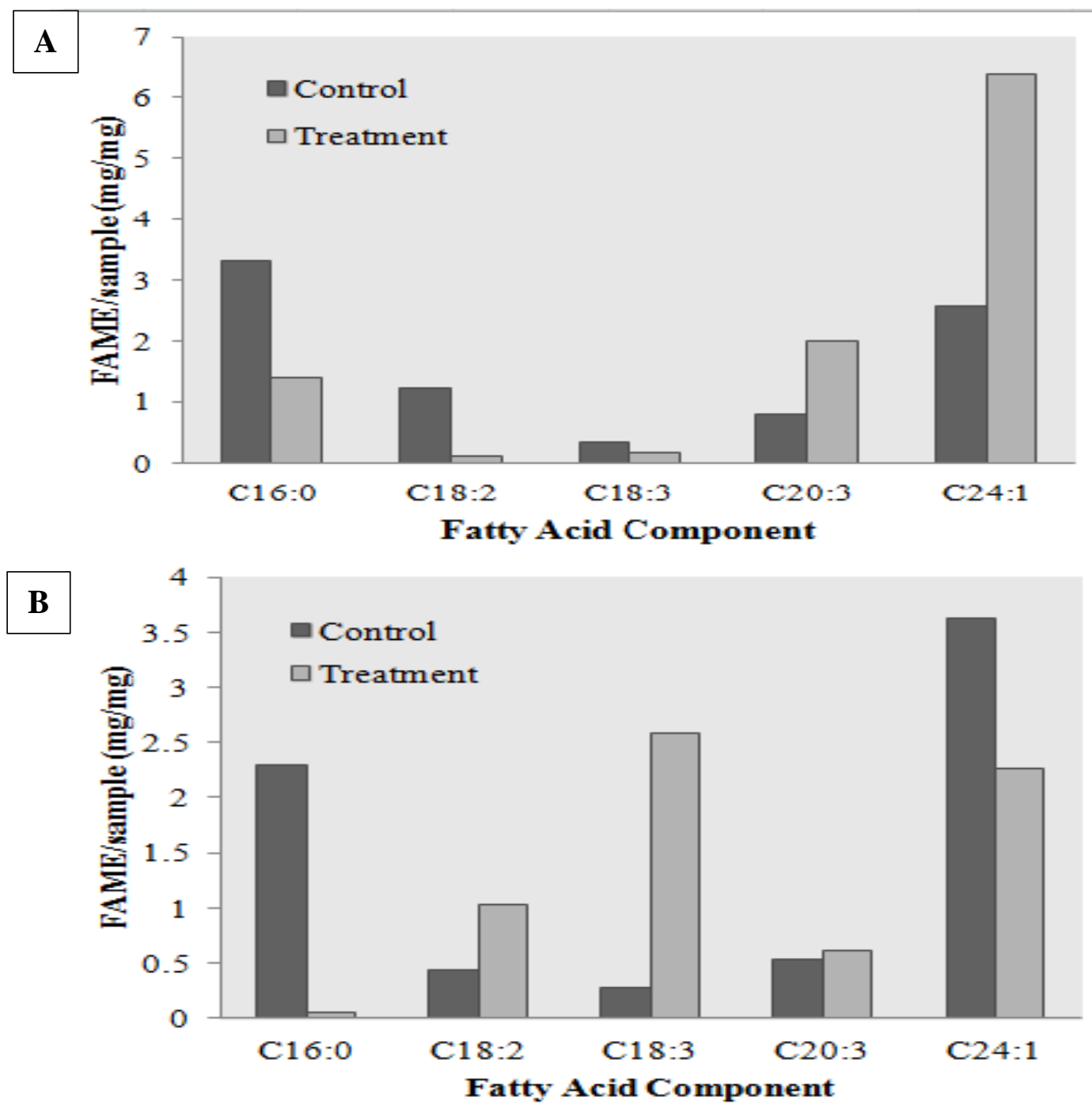

Figure 2: The fatty acid content in FAME sample of leaf (A) and panicle (B) for both control and treatment condition

The dihomo- $\gamma$-linolenic acid (20:3) was the second fatty acid that significantly increased in the leaves of AA treatment, which was 1.23 $\mathrm{mg} / \mathrm{mg}$ sample. Results also showed that five fatty acids were dominant in all samples, which were $16: 0,18: 2,18: 3,20: 3$ and $24: 1$ as shown in Figure 2. Meanwhile, the 18:2 and 18:3 were two fatty acids that significantly increased in the panicles of AA treatment. It was 0.59 $\mathrm{mg} / \mathrm{mm}$ and $2.3 \mathrm{mg} / \mathrm{mg}$ of sample, respectively. The current finding showed that exogenous AA controlled the membrane cell from releasing the FFA to the cell. Only two fatty acids were released as FFA in leaves, i.e. C24:1 and C20:3. While in the panicles were the C18:2 and $\mathrm{C} 18: 3$. The $\mathrm{C} 18: 3$ released might be used as precursor for the jasmonates biosynthesis (Schaller et al., 2004). The 13 (S)-hydroperoxy linolenic acid can be converted into several other compounds via oxidation process such as 18:2, 18:1 and 16:1 (Conconi et al., 1996; Schaller et al., 2004). Current finding also exhibited that the amount of palmitic acid released under salt stress was inhibited by the exogenous AA in both leaves and panicles (Figure 2). The C16:0 is one of the major constituents released by plant plasma membrane to defend the plant towards injury and stresses. The C16:0 then will be converted into longer fatty acid chain (Adjepong et al., 2017) such as the C24:1. Research has shown that environmental stresses, such as drought, 
cold, salt, and heat, can induce changes in fatty acid composition, especially the content of linolenic acid (Aziz et al., 2015; Sui et al., 2018).

\section{Conclusion}

The exogenous AA plays an important role in facilitating plant defence mechanism against salinity stress in rice plant. It regulates the release of FFA from plasma membrane into the cell. The exogenous AA also increases the percentage or number of fill-in grain per panicle. Therefore, higher accumulation of polyunsaturated fatty acids such as the $\alpha$ linolenic acid and dihomo- $\gamma$-linolenic acid maybe involved in the regulation of starch transport and storage in rice under salinity stress. Nonetheless, further study is required to confirm the contribution of PUPA in grain filling process.

\section{Acknowledgements}

Authors thank Universiti Malaysia Terengganu for providing the facilities. This study was funded by the Ministry of Education Malaysia under FRGS grant vote number 59428

\section{References}

Adam, O., Tesche, A., \& Wolfram, G. (2008). Impact of linoleic acid intake on arachidonic acid formation and eicosanoid biosynthesis in humans. Prostaglandins, Leukotrienes and Essential Fatty Acids, 79(3-5), 177-181. https://doi.org/10.1016/j.plefa.2008.09.00 7

Adjepong, M., Valentini, K., Pickens, C. A., Li, W., Appaw, W., \& Fenton, J. (2017). Quantification of fatty acid and mineral levels of selected seeds, nuts, and oils in Ghana. Journal of Food Composition and Analysis, 59, 43-49. https://doi.org/10.1016/j.jfca.2017.02.007

Aguilar, M., Fernández-Ramírez, J. L., Aguilar-Blanes, M., \& Ortiz-Romero, C.
(2017). Rice sensitivity to saline irrigation in Southern Spain. Agricultural Water Management, 188, 21-28. https://doi.org/10.1016/j.agwat.2017.03.0 27

Ali, Y., Aslam, Z., Ashraf, M. Y., \& Tahir, G. R. (2004). Effect of salinity on chlorophyll concentration, leaf area, yield and yield components of rice genotypes grown under saline environment. International Journal of Environmental Science \& Technology, 1(3), 221-225. https://doi.org/10.1007/BF03325836

Amacher, J. K., Koening, R., \& Kitchen, B. (2000). Salinity and Plant Tolerance. All Archived Publications. Retrieved from http://digitalcommons.usu.edu/extension_ histall/43

Aziz, A., Siti Fairuz, Abdullah, M. Z., Marziah, M., \& Nyuk Ling, M. (2015). Fatty acid profile of salinity tolerant rice genotypes grown on saline soil. Malaysian Applied Biology, 44(1), 119-124.

Balkan, A., Genctan, T., Bilgin, O., \& Ulukan, D. H. (2015). Response of rice (Oryza sativa L.) to salinity stress at germination and early seedling stages. Pakistan Journal of Agricultural Sciences, 52, 455461.

Browse, J. (2009). The power of mutants for investigating jasmonate biosynthesis and signaling. Phytochemistry, 70(13-14), 1539-1546. https://doi.org/10.1016/j.phytochem.2009. 08.004

Cai, Q., Yuan, Z., Chen, M., Yin, C., Luo, Z., Zhao, X., ... Zhang, D. (2014). Jasmonic acid regulates spikelet development in rice. Nature Communications, 5. https://doi.org/10.1038/ncomms4476

Cha, T. S., Chen, J. W., Goh, E. G., Aziz, A., \& Loh, S. H. (2011). Differential regulation of fatty acid biosynthesis in two Chlorella 
species in response to nitrate treatments and the potential of binary blending microalgae oils for biodiesel application. Bioresource Technology, 102(22), 1063310640.

https://doi.org/10.1016/j.biortech.2011.09 .042

Conconi, A., Miquel, M., Browse, J. A., \& Ryan, C. A. (1996). Intracellular levels of free linolenic and linoleic acids increase in tomato leaves in response to wounding. Plant Physiology, 111(3), 797-803.

Dasgupta, S., Hossain, M. M., Huq, M., \& Wheeler, D. (2015). Climate change and soil salinity: The case of coastal Bangladesh. Ambio, 44(8), 815-826. https://doi.org/10.1007/s13280-015-06815.

Garcia-Pineda, E., \& Lozoya-Gloria, E. (1999). Induced gene expression of 1aminocyclopropane-1-carboxylic acid

(ACC oxidase) in pepper (Capsicum annuum L.) by arachidonic acid. Plant Science, 145(1), 11-21. https://doi.org/10.1016/S01689452(99)00065-5.

Ghosh, B., Ali, Md. N., \& Saikat, G. (2016). Response of rice under salinity stress: A Review Update. J Res Rice 4:167. doi: 10.4172/2375-4338.1000167

Fonseca, S., Chico, J. M., \& Solano, R. (2009). The jasmonate pathway: the ligand, the receptor and the core signalling module. Current Opinion in Plant Biology, 12(5), 539-547. https://doi.org/10.1016/j.pbi.2009.07.013

Hou, J., Wang, H., Fu, B., Zhu, L., Wang, Y., \& Li, Z. (2016). Effects of plant diversity on soil erosion for different vegetation patterns. CATENA, 147, 632-637. https://doi.org/10.1016/j.catena.2016.08.0 19
Huai, D., Zhang, Y., Zhang, C., Cahoon E.B., \& Zhou, Y. (2015). Combinatorial effects of fatty acid elongase enzymes on nervonic acid production in Camelina sativa. PLoS ONE 10(6): e0131755. https://doi.org/10.1371/journal.pone.01317 $\underline{55}$

Huang, L., Liu, X., Wang, Z., Liang, Z., Wang, M., Liu, M., \& Suarez, D. L. (2017). Interactive effects of $\mathrm{pH}, \mathrm{EC}$ and nitrogen on yields and nutrient absorption of rice (Oryza sativa L.). Agricultural Water Management, $\quad$ 194, 48-57. https://doi.org/10.1016/j.agwat.2017.08.0 12

Khan, M. S. A., Hamid, A., \& Karim, M. A. (1997). Effect of sodium chloride on germination and seedling characters of different types of rice (Oryza sativa L.). Journal of Agronomy and Crop Science, 179(3), 163-169. https://doi.org/10.1111/j.1439037X.1997.tb00512.x

Kibria, M. G., Hossain, M., Murata, Y., \& Hoque, M. A. (2017). Antioxidant defense mechanisms of salinity tolerance in rice genotypes. Rice Science, 24(3), 155-162. https://doi.org/10.1016/j.rsci.2017.05.001

Küpper, F. C., Gaquerel, E., Cosse, A., Adas, F., Peters, A. F., Müller, D. G., ... Potin, P. (2009). Free fatty acids and methyljasmonate trigger defense reactions in Laminaria digitata. Plant and Cell Physiology, 50(4), 789-800. https://doi.org/10.1093/pcp/pcp023

Lyons, R., Manners, J. M., \& Kazan, K. (2013). Jasmonate biosynthesis and signaling in monocots: a comparative overview. Plant Cell Reports, 32(6), 815-827. https://doi.org/10.1007/s00299-013-1400y

Mansour, M. M. F. (2013). Plasma membrane permeability as an indicator of salt tolerance in plants. Biologia Plantarum, 
$57(1)$

$1-10$. https://doi.org/10.1007/s10535-012-01449

Reddy, I. N. B. L., Kim, B.-K., Yoon, I.-S., Kim, K.-H., \& Kwon, T.-R. (2017). Salt tolerance in rice: Focus on mechanisms and approaches. Rice Science, 24(3), 123144.

https://doi.org/10.1016/j.rsci.2016.09.004

Reddy, N., \& Crohn, D. M. (2014). Effects of soil salinity and carbon availability from organic amendments on nitrous oxide emissions. Geoderma, 235-236, 363-371. https://doi.org/10.1016/j.geoderma.2014.0 7.022 .

Roualdes, S., \& Rouessac, V. (2017). 1.10 Plasma Membranes. In Comprehensive Membrane Science and Engineering (Second Edition) (pp. 236-269). Oxford: Elsevier. https://doi.org/10.1016/B978-012-409547-2.12224-3

Sacała, E., Biegun, A., Demczuk, A., \& Grzyś, E. (2011). Effect of $\mathrm{NaCI}$ and supplemental calcium on growth parameters and nitrate reductase activity in maize. Acta Societatis Botanicorum Poloniae, 74(2), 119-123. https://doi.org/10.5586/asbp.2005.016

Salama, K. H. A., Mansour, M. M. F., Ali, F. Z. M., \& Abou-hadid, A. F. (2007). NaClinduced changes in plasma membrane lipids and proteins of Zea mays L. cultivars differing in their response to salinity. Acta Physiologiae Plantarum, 29(4), 351-359. https://doi.org/10.1007/s11738-007-00443

Schaller, F., Schaller, A., \& Stintzi, A. (2004). Biosynthesis and metabolism of Jasmonates. Journal of Plant Growth Regulation, 23(3), 179-199. https://doi.org/10.1007/s00344-004-0047$\mathrm{x}$
Scholz, S. S., Reichelt, M., Boland, W., \& Mithöfer, A. (2015). Additional evidence against jasmonate-induced jasmonate induction hypothesis. Plant Science, 239, 9-14.

https://doi.org/10.1016/j.plantsci.2015.06. 024.

Sui, N., Wang, Y., Liu, S., Yang, Z., Wang, F., \& Wan, S. (2018). Transcriptome and physiological evidence for the relationship between unsaturated fatty acid and salt stress in peanut. Frontier Plant Science, 9:7, doi:10.3389/fpls.2018.00007

Tadesse Gi, B., Mohammed A, H., \& Assefa Geb, A. (2017). Effect of Salinity on Final Growth Stage of Different Rice (Oryza sativa L.) Genotypes. Asian Journal of Agricultural Research, 11(1), 1-9. https://doi.org/10.3923/ajar.2017.1.9

Tanaka, W., Toriba, T., \& Hirano, H.-Y. (2014). Flower Development in Rice. In: F. Fornara (Ed.), Advances in Botanical Research (Vol. 72, pp. 221-262). Academic Press. https://doi.org/10.1016/B978-0-12417162-6.00008-0

Tarakcioglu, C., \& Inal, A. (2002). Changes induced by salinity, demarcating specific ion ratio and osmolity in ion and proline accumulation, and growth perfomance of lettuce. Journal of Plant Nutrition, 25(1), 27-41. https://doi.org/10.1081/PLN100108778

Tian, J., Ji, H., Oku, H., \& Zhou, J. (2014). Effects of dietary arachidonic acid (ARA) on lipid metabolism and health status of juvenile grass carp, Ctenopharyngodon idellus. Aquaculture, 430, 57-65. https://doi.org/10.1016/j.aquaculture.2014 .03.020.

Wei, H., Meng, T., Li, X., Dai, Q., Zhang, H., \& Yin, X. (2018). Sink-source relationship during rice grain filling is associated with grain nitrogen concentration. Field Crops 
Research, 215, 23-38. https://doi.org/10.2135/cropsci2000.4049 https://doi.org/10.1016/j.fcr.2017.09.029 96x

Yuan, Z., \& Zhang, D. (2015). Roles of jasmonate signalling in plant inflorescence and flower development. Current Opinion in Plant Biology, 27, 44-51. https://doi.org/10.1016/j.pbi.2015.05.024

Zeng, L., \& Shannon, M. C. (2000). Salinity effects on seedling growth and yield components of rice, 40(4), 996-1003.
Zeng, L., Shannon, M. C., \& Lesch, S. M. (2001). Timing of salinity stress affects rice growth and yield components. Agricultural Water Management, 48(3), 191-206. https://doi.org/10.1016/S03783774(00)00146-3 